\title{
Solubilization of Inorganic Phosphates and Plant Growth Promotion by Pantoea Strains
}

\author{
Buddhi Charana Walpola, Won-Sik Kong', and Min-Ho Yoon* \\ Department of Bio-Environmental Chemistry, College of Agriculture and Life Sciences, Chungnam National University, \\ Daejeon, 305-764, Korea \\ ${ }^{1}$ Mushroom Research Division, National Institute of Horticultural \& Herbal Science, RDA, Eumseong 369-873, Korea
}

(Received: July 17 2013, Accepted: November 20 2013)

Two phosphate solubilizing Pantoea strains ( $P$. agglomerans and $P$. rodasii) were employed in elucidating their phosphate solubilizing potential under different carbon and nitrogen sources, $\mathrm{pH}$, temperature and salt conditions. Plant growth promoting characteristics such as ACC deaminase activity, indole acetic acid (IAA), HCN, ammonia, and siderophore production of the two strains were assessed in vitro. Potential applicability of the strains as bio-inoculants was also evaluated in pot experiments conducted under green house conditions. Phosphate solubilization measured as the amount of phosphorous released into the medium was recorded as 810 and $788 \mu \mathrm{g} \mathrm{ml}^{-1}$ respectively by $P$. agglomerans and $P$. rodasii. Glucose at the rate of $2 \%$ was found be the best carbon source, while $\left(\mathrm{NH}_{4}\right)_{2} \mathrm{SO}_{4}$ was the best nitrogen source for both strains. Despite a slight decrease in phosphate solubilization observed at higher temperature, $\mathrm{pH}$ and salt concentrations, both strains could withstand against a range of temperature $\left(30-35^{\circ} \mathrm{C}\right.$ ), $\mathrm{pH}(7-9)$ and the presence of $\mathrm{NaCl}$ (up to $5 \%$ ) without much compromising the phosphate solubilization. Different plant growth promoting traits (ACC deaminase activity, IAA, HCN, ammonia, and siderophore production) of the strains and their ability to promote the growth of green gram seedlings indicate that both strains possess high potential to be used as bio-inoculants.

Key words: Pantoea agglomerans, Pantoea rodasii, phosphate solubilization

Plant growth promoting characteristics and results of the pot experiment.

\begin{tabular}{|c|c|c|c|}
\hline \multicolumn{4}{|c|}{ Plant growth promoting characteristics } \\
\hline Ammonia production & \multicolumn{2}{|c|}{ Positive } & \\
\hline $\mathrm{HCN}$ production & \multicolumn{2}{|c|}{ Positive } & \\
\hline \multirow[t]{3}{*}{ ACC deaminase activity } & \multicolumn{2}{|c|}{ Positive } & \\
\hline & \multicolumn{2}{|c|}{ Inoculated } & \\
\hline & P. agglomerans & $P$. rodasii & Un-inoculated \\
\hline Shoot length (cm) & 24.52 & 25.22 & 15.34 \\
\hline Root length $(\mathrm{cm})$ & 16.83 & 18.56 & 10.64 \\
\hline
\end{tabular}

*Corresponding author : Phone: +82428216733, Fax: +82428239241, Email: mhyoon@cnu.ac.kr

${ }^{\S}$ Acknowledgement: This study was supported by a grant from the research project (No. PJ0067492011) of National Institute of Horticultural \& Herbal Science, Rural Development Administration, Republic of Korea. 


\section{Introduction}

Phosphate solubilizing bacteria are known to be effectively involved in the transformation of insoluble phosphate to soluble forms enhancing the nutrient status of the soil (Lugo et al., 2008; Son et al., 2006; Souchie et al., 2006). This process not only compensates high cost of phosphatic fertilizer production but also minimizes environmental contamination.

Positive impacts of phosphate solubilizing bacteria on growth and phosphorous uptake by plants have been reported consistantly (Reyes et al., 2002; Zaidi et al., 2003; Nezarat and Gholami, 2009; Collavino et al., 2010). However, the performance of these bacteria varies highly with the prevailing environmental conditions such as temperature, $\mathrm{pH}$ and salt concentration of the soils. Furthermore, bacterial population generally decreases upon inoculation, thus target strain is needed to be inoculated at higher concentrations (Jain et al., 2010).

The degree of phosphate solubilization depends on various physico-chemical factors viz. nature and amount of phosphate sources, $\mathrm{pH}$, temperature, salt and acid concentration. Apart from them, carbon and nitrogen sources and their concentrations also have strong influence on phosphate solubilization (Relwani et al., 2008; Dave and Patel, 2003). It has been reported that microbial-mediated production of desired products (enzymes, organic molecules) can be augmented through the optimization of culture conditions (Scervino et al., 2010). Therefore, it is apparent that phosphate solubilizing bacteria should be provided with optimum combination of physico-chemical factors along with the energy sources in order to achieve greater phosphate solubilization.

As revealed by the previous studies, Pantoea spp. are considered being efficient phosphate solubilizers (Son et al., 2006; Dastager et al., 2009; Malboodi et al., 2009). Despite the fact that these species can be cultured competently, their phosphate solubilizing potential under varying culture conditions are worth investigating, because such information would be vital in developing successful inoculum production programmes.

The present study was under taken to evaluate phosphate solubilizing potential of two Pantoea species under different carbon and nitrogen sources, $\mathrm{pH}$, temperature and salt conditions. In addition, their other plant growth promoting characteristics such as production of indole acetic acid (IAA), HCN, ammonia, and siderophore, and ACC deaminase activity were also assayed. The effectiveness of the strains as bio-inoculants was assessed in pot experiments conducted under green house conditions.

\section{Materials and Methods}

Isolation of phosphate solubilizing bacterial strains Soils collected from the button mushroom media at Chungchugnamdo province, Buyeo-Gun area in South Korea were used in isolating bacterial strains. The mushroom media were shacked into a sterile polythene bag in order to collect the soil adhering to the media. They were immediately transported to the laboratory and $10 \mathrm{~g}$ of moist soil from each mushroom samples was weighed and transferred to $250 \mathrm{ml}$ Erlenmeyer flask containing sterilized $90 \mathrm{ml}$ of $0.85 \% \mathrm{NaCl}$ solution. The mixture was then shaken for 30 minutes at approximately $150 \mathrm{rpm}$. Immediately after shaking, a series of tenfold dilutions of the suspension was made by pipetting $1 \mathrm{ml}$ aliquot into sterilized $9 \mathrm{ml}$ of $0.85 \% \mathrm{NaCl}$ solution. Aliquots of $0.1 \mathrm{ml}$ of the sample from each of these dilutions were spread on to a petri dish with National Botanical Research Institute Phosphorus (NBRIP) medium containing $10 \mathrm{~g}$ of glucose, $5 \mathrm{~g}$ of $\mathrm{Ca}_{3}\left(\mathrm{PO}_{4}\right)_{2}, 5 \mathrm{~g}$ of $\mathrm{MgCl}_{2} \cdot 6 \mathrm{H}_{2} \mathrm{O}, 0.25 \mathrm{~g}$ of $\mathrm{Mg}$ $\mathrm{SO}_{4} .7 \mathrm{H}_{2} \mathrm{O}, 0.2 \mathrm{~g}$ of $\mathrm{KCl}$ and $0.1 \mathrm{~g}$ of $\left(\mathrm{NH}_{4}\right)_{2} \mathrm{SO}_{4}$ in $1 \mathrm{~L}$ distilled water (Nautiyal, 1999). The $\mathrm{pH}$ of the media was adjusted to 7 using $\mathrm{HCl}$. The plates were incubated for 7 days in an incubator at $30^{\circ} \mathrm{C}$. The colonies with clear halos were considered to be phosphate solubilizing colonies. Predominant colonies were further purified by re-streaking on the fresh NBRIP agar plates at $30^{\circ} \mathrm{C}$.

16S rDNA gene sequencing and Phylogenetic analysis of the isolated bacteria The partial sequencing of 16S rRNA for the bacterial strains was done with the help of DNA sequencing service, SOLGENT, Daejeon, South Korea using universal primers, 27F (5'-AGAGTTTGATCCTGGCT CAG -3 ') and 1492R (5'-GGTTACCTTGTTACGACTT-3'). The online program BLAST was used in identifying the related sequences with known taxonomic information available at the databank of NCBI (http://www.ncbi.nlm.nih.gov/BLAST). A Phylogenetic tree was constructed using CLUSTAL X program (Thompson et al., 1997), which involved sequence alignment by neighbor joining method (Saitou and Nei, 1987) and maximum parsimony using the MEGA4 program (Kumar et al., 2001). Grouping of sequences was based on confidence values obtained by bootstrap analysis of 1,000 replicates. Gaps were edited in the BioEdit program and evolutionary distances were calculated using Kimura two parameter model. Reference sequences were retrieved from GenBank under the accession numbers indicated in the trees.

Optimum culture condition for phosphate solubilization Bacterial strains were grown in sterilized liquid NBRIP medium $(20 \mathrm{ml})$ at $30^{\circ} \mathrm{C}$ for 2 days with continuous shaking at $150 \mathrm{rpm}$. Aliquots of culture $(1 \mathrm{ml})$ having diluted to $10^{6} \mathrm{CFU} \mathrm{ml}^{1-}$ was then transferred to a $500 \mathrm{ml}$ flask ( $\mathrm{n}=3$ per strain) containing sterilized liquid NBRIP medium (200 ml) and incubated for 7 days with continuous 
shaking at $30^{\circ} \mathrm{C}$. The same non-inoculated medium served as control in each case. A sample $(10 \mathrm{ml})$ of each cultured and control were taken daily and centrifuged at $8000 \mathrm{rpm}$ for $15 \mathrm{~min}$. The clear supernatant was used in determining the amount of phosphorous released into the medium. The $\mathrm{pH}$ of the culture medium was also recorded with the $\mathrm{pH}$ meter equipped with glass electrode. The phosphorus availability was determined using phospho-molybdate blue color method (Murphy and Riley, 1962).

Phosphate solubilizing ability of bacterial strains was tested under different carbon and nitrogen sources. Effect of carbon source on phosphate solubilization was tested by using monosaccharides (D-Galactose, D-fructose, D- Xylose), disaccharides (lactose, maltose, sucrose) and derivatives sugar (D-sorbitol, D-mannitol) instead of glucose in the NBRIP medium. To test the effect of the nitrogen source, $\left(\mathrm{NH}_{4}\right)_{2} \mathrm{SO}_{4}$ in the NBRIP medium was replaced by $\mathrm{NH}_{4} \mathrm{Cl}$, $\mathrm{NH}_{4} \mathrm{NO}_{3}, \mathrm{KNO}_{3}, \mathrm{NaNO}_{3}$ and $\mathrm{Ca}\left(\mathrm{NO}_{3}\right)_{2}$.

The effect of salt on phosphate solubilization was tested by growing the strains on NBRIP containing various concentrations of $\mathrm{NaCl}(0,2.5,5$ and $10 \%)$. Further, the effect of $\mathrm{pH}$ on phosphate solubilization was tested by adjusting the $\mathrm{pH}$ of NBRIP medium using $\mathrm{HCl}$ or $\mathrm{NaOH}$ to different $\mathrm{pH}$ levels (7-10). For estimation of high temperature induced phosphate solubilization, NBRIP medium inoculated with strains was incubated at different temperature conditions $\left(30-40^{\circ} \mathrm{C}\right)$. In all cases, phosphate solubilization and $\mathrm{pH}$ of the culture medium were measured as described earlier and experiments were performed in triplicate. The absolute value of the control refers to the amount of phosphorus solubilized $\left(\mu \mathrm{g} \mathrm{ml}^{1-}\right)$ by each strain when individually grown for 3 days in NBRIP medium under the $30^{\circ} \mathrm{C}$ temperature, $\mathrm{pH} 7$ and in the presence of $0 \%$ salt $(\mathrm{NaCl})$.

Assay of plant growth promoting characteristics ACC deaminase (1-aminocyclopropane-1-carboxylic acid) activity was assayed according to Penrose and Glick (2003). Solid DF minimal medium containing ACC was inoculated with $10 \mu \mathrm{l}$ of starter culture (grown overnight at $30^{\circ} \mathrm{C}$ ). Plates were then incubated at $30^{\circ} \mathrm{C}$ in dark and colony emergence was checked daily for consecutive 3 days.

IAA (Indole acetic acid) production was determined using the method described by Gutierrez et al. (2009). The strain grown in sterilized liquid NBRIP medium (100 $\mathrm{ml}$ ) containing $1 \mathrm{ml}$ of $0.2 \%$ tryptopan was incubated for $36 \mathrm{hrs}$ with continuous shaking at $30^{\circ} \mathrm{C}$. IAA production was measured every 12 hours. For that centrifuged clear supernatant of $1 \mathrm{ml}$ was mixed with $4 \mathrm{ml}$ of the Salkowski's reagent $(50 \mathrm{ml}$ of $35 \%$ perchloric acid and $1 \mathrm{ml}$ of 0.05 $\mathrm{M} \mathrm{FeCl}_{3}$ solution). Development of pink color indicated the IAA production, which was then quantified with optical density measurements taken at $530 \mathrm{~nm}$ using UV spectrophotometer (Shimadzu UV-VIS).

Ammonia production was tested using peptone water. Fresh cultures were inoculated into $10 \mathrm{ml}$ peptone water and incubated for $48 \mathrm{hrs}$ at $30^{\circ} \mathrm{C}$. Nessler's reagent $(0.5$ $\mathrm{ml}$ ) was added to each tube. Development of brown to yellow colour indicated the production of ammonia (Cappucino and Sherman, 1992).

HCN production was assessed by growing the bacteria in $10 \%$ tryptic soy agar (TSA) supplemented with glycine $\left(4.4 \mathrm{~g} \mathrm{~L}^{-1}\right)$. Filter paper soaked in picric acid and $\mathrm{Na}_{2} \mathrm{CO}_{3}$ ( $0.5 \%$ and $2 \%$ respectively) was fixed to the underside of the lids of plates and incubated for 5 days at $30^{\circ} \mathrm{C}$. A change in filter paper color from yellow to orange-brown was considered to be the indication of $\mathrm{HCN}$ production (Donate-Correa et al., 2005).

For quanttiative determination of siderophore production, modified succinate medium ( $1 \mathrm{~L})$ containing $4 \mathrm{~g}$ succinic

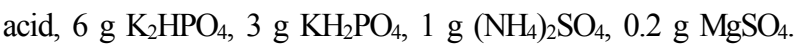
$7 \mathrm{H}_{2} \mathrm{O}$ was used to inoculate $24 \mathrm{hrs}$ old cultures of Pantoea strains. It was incubated for $72 \mathrm{hrs}$ with continuous shaking at $30^{\circ} \mathrm{C}$. A sterilized uninoculated medium was served as the control. Each sample was taken into centrifugation tube for every $24 \mathrm{hrs}$ and centrifuged for $10 \mathrm{~min}$ at 10000 rpm. The clear supernatant was subjected to detection of siderophore production as described by Schwyn and Neilands (1987). Quantitative estimation of siderophores was done by CAS-shuttle assay (Payne, 1994). Culture supernatant $(0.5 \mathrm{ml})$ was mixed with same amount of CAS reagent $(0.5 \mathrm{ml})$ and absorbance was measured at $630 \mathrm{~nm}$ against a reference Siderophore content in the aliquots were calculated using following formula.

$$
\begin{aligned}
& \% \text { Siderophore units }=\frac{\mathrm{Ar}-\mathrm{As}}{\mathrm{As}} \times 100 \\
& \mathrm{Ar}-\text { Absorbance of reference } \\
& \mathrm{As}-\text { Absorbance of sample }
\end{aligned}
$$

Plant growth promotion bioassay with green gram (Vigna radiata) Green gram (Vigna radiata var. paiyur 1) seeds were surface sterilized by immersing in $0.1 \%$ sodium hypochlorite solution for 10 minutes followed by washing with distilled water. Seeds were soaked in bacterial suspensions at the concentration of $10^{8} \mathrm{CFU} \mathrm{ml}{ }^{-1}$ about $30 \mathrm{~min}$ prior to planting. Inoculated seeds were placed in earthen pots (six seeds/pot) and covered with a $15 \mathrm{~mm}$ thick uniform soil layer. Control plants received seeds soaked in diluted nutrient broth with no bacteria. Pots were watered daily to maintain moisture at field capacity during the study period. After one week of germination, plants were thinned out allowing 3 plants per pot to remain. Growth promotion effects of bacterial treatments were assessed by measuring 
shoot and root length of green gram plants after 4 weeks of planting.

Statistical analysis The data were subjected to analysis of variance (ANOVA) using SAS package (SAS, 1999). The Duncan's Multiple Range Test (DMRT) was applied to test the significance of treatment means at $\mathrm{P} \leq 0.05$.

\section{Results and discussion}

Isolation and identification of phosphate solubilizing bacterial strains Selected bacterial strains showed a marked solubilizing ability of inorganic phosphate as visualized by the clear zone developed around the colony after 3 days of incubation. According to $16 \mathrm{~S}$ rRNA sequence analysis, the strains showed close proximity (>99\%) with Pantoea agglomerans DSM3493 (Accession number AJ233423.1) and Pantoea rodasii LGM 26273 (Accession number
JF295053.1). Phylogenetic tree (Fig. 1) shows the position of isolated phosphate solubilizing bacterial strain with respect to related species. Different Pantoea stains have previously been identified as efficient phosphate solubilizers (Son et al., 2006; Malboodi et al., 2009; Khalim et al., 2012; Collavino et al., 2010; Viruel et al., 2011; SiliniCherif et al., 2012).

Optimum culture conditions for phosphate solubilization Fig. 2 and 3 represents the results of inorganic phosphate solubilization by isolated Pantoea strains and the associated $\mathrm{pH}$ changes in the NBRIP medium during the 7-day incubation period. Both strains exhibited more or less similar capacity to solubilize inorganic phosphate $(810 \mu \mathrm{g}$ $\mathrm{ml}^{1-}$ in $P$. agglomerans and $788 \mu \mathrm{g} \mathrm{ml}{ }^{1-}$ in $P$. rodasii at the end of 7-day incubation). Phospahate solubilization in NBRIP medium inoculated with $P$. agglomerans, occurred predominantly during the first 1-2 days of the incubation,

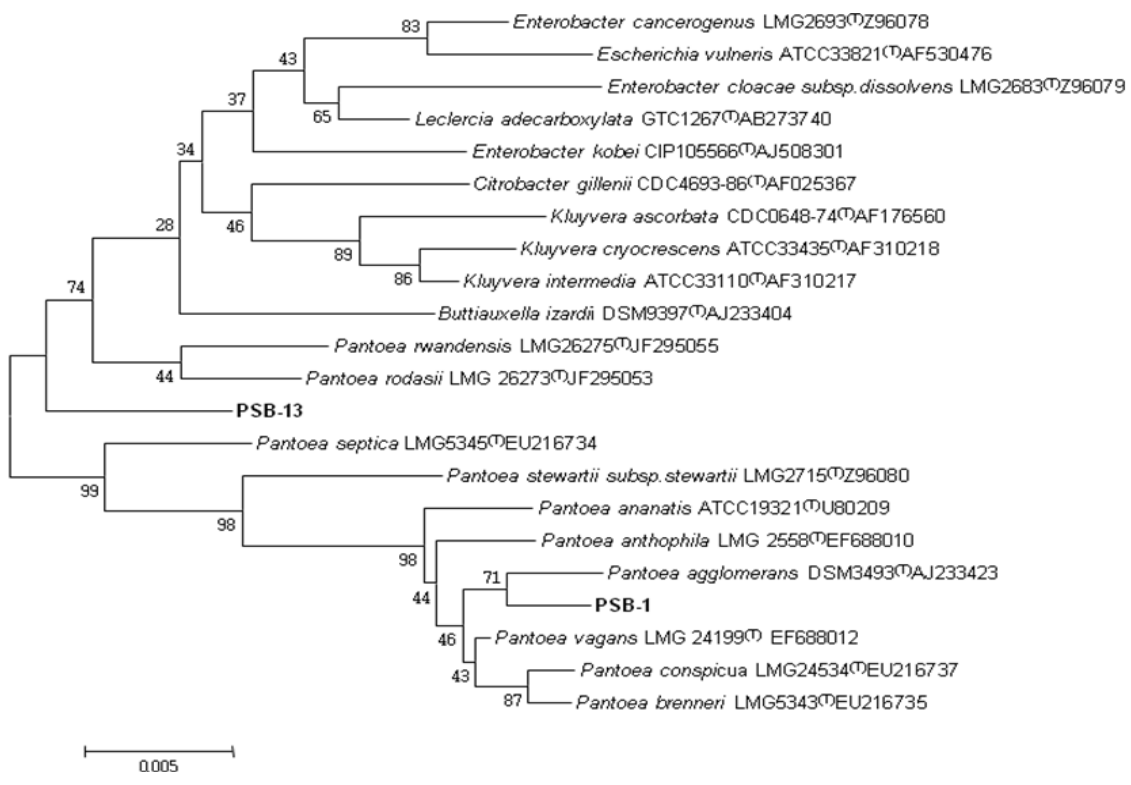

Fig 1. Phylogenetic tree based on 16S rRNA gene sequences, showing the position of Pantoea agglomerans and Panotea rodasii strains with respect to related species. The scale bar indicates 0.005 substitutions per nucleotide position and accession numbers are given in parenthesis.

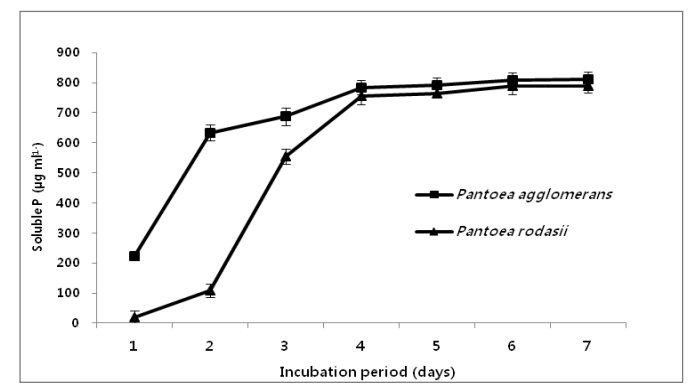

Fig 2. Phosphate solubilization by Pantoea agglomerans and Fig 3. Changes of pH in NBRIP culture medium containing Pantoea Panotea rodasii strains grown in NBRIP medium at $300 \mathrm{C}$. Values are the means $(n=3) \pm$ standard deviation.

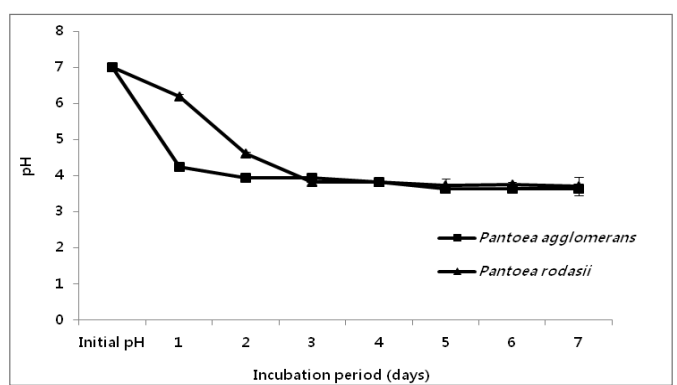

agglomerans and Panotea rodasii strains grown in NBRIP medium at 30oC. Values are the means $(n=3) \pm$ standard deviation. 
Table 1. Effect of various carbon and nitrogen sources on phosphate solubilization by Pantoea agglomerans and Pantoea rodasii.

\begin{tabular}{|c|c|c|}
\hline & \multicolumn{2}{|c|}{$\begin{array}{c}\text { Phosphate solubilization compared to } \\
\text { control }(\%)\end{array}$} \\
\hline & Pantoea agglomerans & Pantoea rodasii \\
\hline Control & $100(3.93)$ & $100(3.62)$ \\
\hline Absolute value & $810.4 \pm 11.45$ & $788.2 \pm 9.25$ \\
\hline \multicolumn{3}{|l|}{ Carbon source } \\
\hline Fructose & $35.6(4.55)$ & $49.1(4.10)$ \\
\hline Galactose & $59.8(4.33)$ & $50.9(4.13)$ \\
\hline Sorbitol & $19.1(5.13)$ & $3.0(6.67)$ \\
\hline Mannitol & $92.2(4.05)$ & $98.6(3.93)$ \\
\hline Xylose & $94.1(3.95)$ & $59.4(4.26)$ \\
\hline Sucrose & $31.2(4.43)$ & $3.6(6.79)$ \\
\hline Maltose & $22.3(4.82)$ & $16.0(4.58)$ \\
\hline Lactose & $50.2(4.32)$ & $17.7(5.27)$ \\
\hline \multicolumn{3}{|l|}{ Nitrogen source } \\
\hline $\mathrm{NH}_{4} \mathrm{Cl}$ & $90.8(4.23)$ & $93.2(3.84)$ \\
\hline $\mathrm{NH}_{4} \mathrm{NO}_{3}$ & $97.7(4.11)$ & $98.8(3.80)$ \\
\hline $\mathrm{KNO}_{3}$ & $72.8(4.29)$ & $72.2(3.96)$ \\
\hline $\mathrm{NaNO}_{3}$ & $31.4(4.86)$ & $21.8(4.62)$ \\
\hline $\mathrm{Ca}_{3}\left(\mathrm{NO}_{3}\right)_{2}$ & $91.9(4.04)$ & $95.5(3.80)$ \\
\hline
\end{tabular}

Control strains were grown for 3 days in NBRIP medium Final $\mathrm{pH}$ of the growth medium is given within the parentheses.

Absolute value of phosphate solubilization $(\mu \mathrm{g} / \mathrm{ml})$ of control corresponding to $100 \%$.

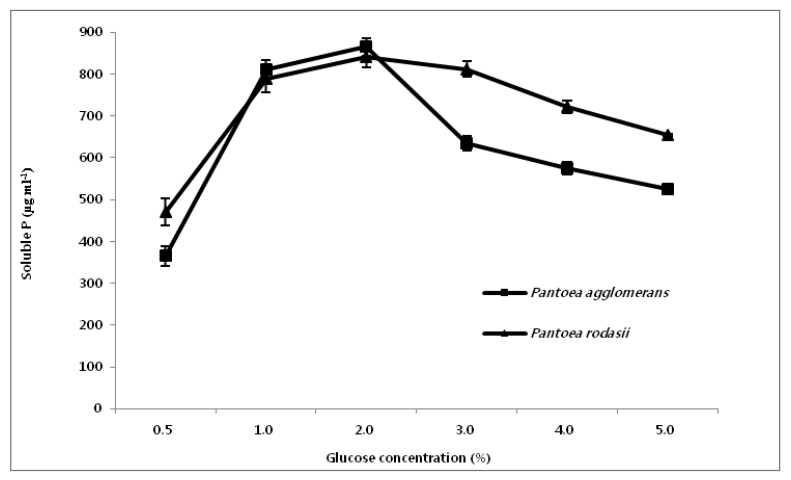

Fig 4. Effect of glucose concentration on phosphate solubilization by Pantoea agglomerans and Panotea rodasii grown in NBRIP medium at $300 \mathrm{C}$. Values are the means $(n=3) \pm$ standard deviation.

whereas for $P$ rodasii, rapid solubilization was recorded during first 2-3 days. However, as incubation progressed, soluble phosphorus content in the medium was found to be decreased. Moreover, both strains lowered the $\mathrm{pH}$ of the medium, and the relative time course coincided with the increase in the phosphate solubilization. At the end of 7-day incubation, the $\mathrm{pH}$ drop by $P$. agglomerans and $P$. rodasii were 3.63 and 3.71 respectively.

Strains response to different carbon and nitrogen sources is depicted in Table 1. Phosphate solubilization by $P$. agglomerans was recorded to be high when glucose, mannitol and xylose were used as the sole source of carbon, while glucose and mannitol were found to be better carbon sources for $P$. rodasii. When the medium was supplemented with sorbitol, maltose or sucrose, poor phosphate solubilization was recorded from $P$. agglomerans. In addition to them, lactose was also recorded to be poor carbon source for $P$. rodasii.

Out of the eight carbon source, glucose was found to be the best source for phosphate solubilization, thus the effect of glucose concentration on phosphate solubilization was assessed by adding different glucose concentrations (ranging from 0.5 to $5 \%$ ) to the NBRIP medium. As shown in Fig. 4, both strains exhibited the maximum phosphate solubilization at the $2 \%$ glucose concentration. Further increase in glucose concentration caused reduction in phosphate solubilization by both strains. Son et al., (2006) isolated phosphate solubilizing bacteria, P. agglomerans R-42, which recorded the maximum phosphate solubilization at $3 \%$ glucose concentration.

As shown in Table 1, both strains exhibited higher phosphate solubilization with all the nitrogen sources except $\mathrm{NaNO}_{3}$, where 31 and $32 \%$ reductions respectively for $P$. agglomerans and $P$. rodasii were observed compared to the control. However, the maximum solubilization was recorded with $\left(\mathrm{NH}_{4}\right)_{2} \mathrm{SO}_{4}$.

As depicted in Table 2, the optimum $\mathrm{pH}$ for phosphate solubilization was recorded to be 7 . However, $P$. rodasii showed considerably high phosphate solubilization even at higher $\mathrm{pH}$ values such as $\mathrm{pH} 8$ and 9 (98 and 96\% increments compared to the control respectively at $\mathrm{pH} 8$ and 9). In the case of $P$. agglomerans, phosphate solubilization was over $50 \%$ higher than the control even at $\mathrm{pH} 10$. Therefore, both strains were shown to be good phosphate solubilizers at wide range of $\mathrm{pH}$ conditions. As reported by Silini-Cherif et al. (2012) and Costa et al. (2002), P. agglomerans Ima2 and $P$. agglomerans CPA-2 could grow both in alkaline and acidic conditions.

Temperature is considered to be the most important factor affecting physiology and growth of microorganisms (Rahman et al., 2006). As shown in Table 2, present strains recorded the maximum phosphate solubilization at $30^{\circ} \mathrm{C}$. Generally performance of bacteria reduces at high temperature conditions (Malboodi et al., 2009), which was further confirmed by the present results of dramatically decreased phosphate solubilization by $P$. rodasii at $35{ }^{\circ} \mathrm{C}$ (37\% reduction compared with the control). However, 
relatively higher phosphate solubilization was recorded by $P$. agglomerans even when temperature increased up to $35^{\circ} \mathrm{C}$.

Bacterial strains that survive in high salt conditions may also successfully colonize with the roots of plants grown under the same conditions (Saleena et al., 2002). Therefore, tolerance to salt is considered to be an important feature, which ensures the growth and survival of microorganisms in soil. The impact of salt concentrations on phosphate

Table 2. Effect of various pH, temperature and salt concentration (NaCl \%) on phosphate solubilization by Pantoea agglomerans and Pantoea rodasii.

\begin{tabular}{lcc}
\hline \hline & \multicolumn{2}{c}{$\begin{array}{c}\text { Phosphate solubilization compared to } \\
\text { control (\%) }\end{array}$} \\
\cline { 2 - 3 } & \multicolumn{2}{c}{$\begin{array}{c}\text { Pantoea agglomerans } \\
\text { Cantoea rodasii }\end{array}$} \\
\hline Absolute value & $8100.4 \pm 11.45$ & $788.2 \pm 9.25$ \\
Initial pH & & \\
8 & $79.5(3.98)$ & $98.1(4.07)$ \\
9 & $60.9(4.16)$ & $96.1(4.15)$ \\
10 & $54.1(4.22)$ & $72.8(5.12)$ \\
Temperature (oC) & & \\
35 & $85.1(3.95)$ & $37.4(4.32)$ \\
40 & $12.3(4.92)$ & $8.7(5.48)$ \\
NaCl (\%) & & \\
2.5 & $67.4(4.14)$ & $98.4(4.08)$ \\
5 & $50.6(4.34)$ & $80.4(4.15)$ \\
7.5 & $13.5(5.12)$ & $6.1(5.92)$ \\
10 & $2.1(6.33)$ & $1.4(6.49)$ \\
\hline
\end{tabular}

Control strains were grown for 3 days in NBRIP medium Final $\mathrm{pH}$ of the growth medium is given within the parentheses.

Absolute value of phosphate solubilization $(\mu \mathrm{g} / \mathrm{ml})$ of control corresponding to $100 \%$.

Table 3. Plant growth promoting characteristics and results of the pot experiment.

\begin{tabular}{|c|c|c|c|}
\hline \multicolumn{4}{|c|}{ Plant growth promoting characteristics } \\
\hline $\begin{array}{l}\text { Ammonia } \\
\text { production }\end{array}$ & \multicolumn{2}{|c|}{ Positive } & \\
\hline $\begin{array}{l}\mathrm{HCN} \\
\text { production }\end{array}$ & \multicolumn{2}{|c|}{ Positive } & \\
\hline \multirow[t]{3}{*}{$\begin{array}{l}\text { ACC } \\
\text { deaminase activity }\end{array}$} & & & \\
\hline & & & \\
\hline & P. agglome & P. rodasii & Un-inoculated \\
\hline Shoot length $(\mathrm{cm})$ & 24.52 & 25.22 & 15.34 \\
\hline Root length (cm) & 16.83 & 18.56 & 10.64 \\
\hline
\end{tabular}

solubilization was assessed by adding $\mathrm{NaCl}$ to culture medium and the amount of soluble phosphorous released into the medium was decreased with increasing salt concentrations. However, $P$. rodasii was able to record more than $80 \%$ phosphate solubilization when compared to the control at 5\% salt concentrations. Therefore $P$. rodasii could be considered as a halotolerant phosphate solubilizer which could be applied to such soils.

Assay of other plant growth promoting characteristics and Plant growth promotion bioassay Results of the assays on ACC deaminase activity, and production of ammonia, HCN, IAA and siderophore are given in Fig. 5, 6 and Table 3. The strains showed positive responses for all the tested plant growth promotion traits. The maximum IAA production $\left(229 \mu \mathrm{g} \mathrm{ml}^{-1}\right)$ was recorded by $P$. rodasii and the highest siderophore production was recorded by P. agglomerans. Similar to the present findings, Pantoea strains with pronounced ACC deaminase activity (Kausar and hahzad 2006; Viveros et al., 2010) and IAA production (Cimmino et al., 2006; Feng et al., 2006) have been reported previously.

Pantoea strains inoculated green gram seedlings showed

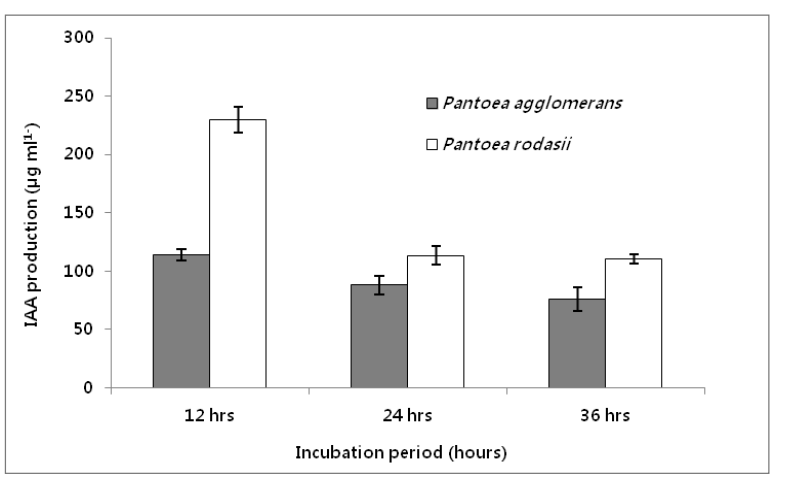

Fig. 5. IAA production $(\mu \mathrm{g} / \mathrm{ml})$ by Pantoea agglomerans and Panotea rodasii. Values are the means $(\mathrm{n}=3) \pm$ standard deviation.

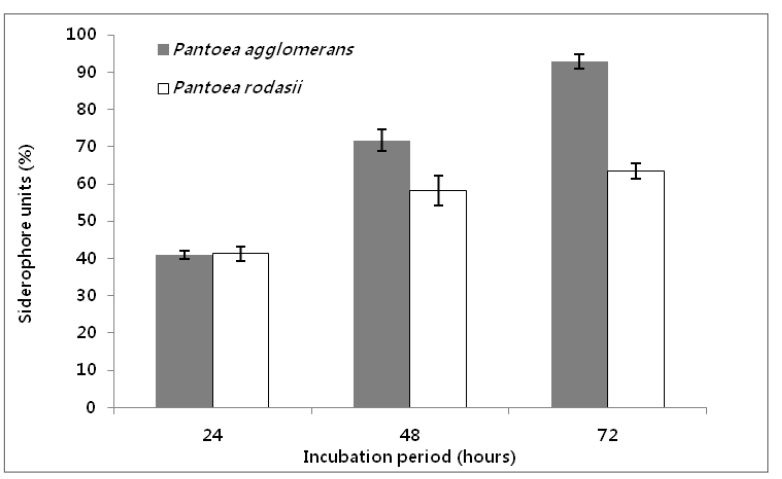

Fig. 6. Siderophore production (\%) by Pantoea agglomerans and Panotea rodasii. Values are the means $(n=3) \pm$ standard deviation. 
significantly higher shoot and root length when compared with un-inoculated plants. Moreover, plants inoculated with $P$. rodasii which demonstrated comparatively lower phosphorus release showed higher shoot and root growth compared to plants inoculated with $P$. agglomerans. Therefore, it is evident that in addition to providing available phosphorus to plants, the isolated strains can enhance the growth of plant through other mechanisms as well. As shown in Table 3, inoculated seedlings recorded higher shoot and root lengths compared to un-inoculated control. Khalim et al. (2012) reported that inoculation of $P$. agglomerans strains $\mathrm{PaJ}$ and $\mathrm{BS} 2$ as a mixture or as single strain effectively increase the growth and yield of rice.

Growth promotion of green gram could be attributed to bacteria-induced absorption of nutrients, particularly $\mathrm{P}$, as well as other plant growth promoting activities of the strains. Based on the results, both strains could be identified as being effective plant growth promoters, thus could be recommended for the production of bio-inoculants.

\section{References}

Cappucino, J.C. and N. Sherman. 1992. Microbiolgy: A laboratory manual. Benjamin/Cummings Publishing Company, New York, pp. 125-179.

Cimmino, A., A. Andolfi, G. Marchi, G. Surico, and A. Evindente. 2006. Phytohormone production by strain Pantoea agglomerans from knot on olive plants caused by Pseu-domonas savastanoi pv.savastanoi. Phytopathol. Mediterr. 45:247-252.

Collavino, M.M., P.A. Sansberro, L.A. Mroginski, and O.M. Aguilar. 2010. Comparison of in vitro solubilization activity of diverse phosphate-solubilizing bacteria native to acid soil and their ability to promote Phaseolus vulgaris growth. Biol. Fert. Soils. 46:727-738.

Costa, E., J.Usall, N.Teixido, J. Delgado, and I. Vinas. 2002. Water activity, temperature, and $\mathrm{pH}$ effects on growth of the biocontrol agent Pantoea agglomerans CPA-2. Can. J. Microbiol. 48:987-992.

Dastager, S.G., C.K. Deepa1, S.C. Puneet, C.S. Nautiyal, and A. Pandey. 2009. Isolation and characterization of plant growthpromoting strain Pantoea NII-186 from Western Ghat forest soil, India. Lett. Appl. Microbiol. doi:10.1111/j.1472-765X. 2009.02616.x

Dave, A. and H.H. Patel. 2003. Impact of different carbon and nitrogen sources on phosphate solubilization by Pseudomonas fluorescens. Indian J. Microbiol. 43:33-36.

Donate-Correa, J., M. Leon-Barrios and R. Perez-Galdona. 2005. Screening for plant growth-promoting rhizobacteria in Chamaecytisus proliferus (tagasaste), a forage tree-shrub legume endemic to the Canary Islands. Plant Soil. 266: 261-272.

Feng, Y., D. Shen, and W. Song. 2006. Rice endophyte Pantoea agglomerans YS19 promotes host plant growth and effects allocations of host photosynthates. J. App. Microbiol. 100:938-945.

Gutierrez, C.K., G.Y. Matsui, D.E. Lincoln, and C.R. Lovell. 2009. Production of the phytohormone indole-3-acetic acid by the estuarine species of the genus Vibrio. Appl. Environ. Microbiol. 75:2253-2258.

Jain, R., J. Saxena, and V. Sharma. 2010. The evaluation of free and encapsulated Aspergillus awamori for phosphate solubilization in fermentation and soil-plant system. Appl. Soil Ecol. 46:90-94.

Kausar, R. and S.M. Hahzad. 2006. Effect of ACC-deaminase Containing Rhizobacteria on Growth Promotion of Maize under Salinity Stress. J. Agri. Soc. Sci. 2:216-218.

Khalim, K., D.N. Suprapta, and Y. Nitta. 2012. Effect of Pantoea agglomerans on growth promotion and yield of rice. Agric. Sci. Res. J. 2:240-249.

Kumar, S., K. Tamura, I.B. Jakobsen, and M. Nei. 2001. MEGA2: molecular evolutionary genetics analysis software. Bioinformatics. 17:1244-1245.

Lugo, M.A., M. Ferrero, E. Menoyo, M.C. Estévez, F. Siñeriz, and A. Anton. 2008. Arbuscular mycorrhizal fungi and rhizospheric bacteria diversity along a altitudinal gradient in South American Puna grassland. Microb. Ecol. 55:705-713.

Malboobi, M.A., P. Owlia, M. Behbahani, E. Sarokhani, S. Moradi, B. Yakhchali, A. Deljou, and K.M. Heravi. 2009. Solubilization of organic and inorganic phosphates by three highly efficient soil bacterial isolates. World J. Microbiol. Biotechnol. 25:1471-1477.

Murphy, J. and J. P. Riley. 1962. A modified single solution method for the determination of phosphate in mineral waters. Anal. Chim. Acta. 27:31-36.

Nautiyal, C.S. 1999. An efficient microbiological growth medium for screening of phosphate solubilizing microorganisms. FEMS Microbiol. Lett. 170:265-270.

Nezarat, S. and A. Gholami. 2009. Screening plant growth promoting rhizobacteria for improving seed germination, seedling growth and yield of maize. Pakistan J. Biol. Sci. 12: 26-32.

Payne, S. M. 1994. Detection, isolation and characterization of siderophores. In:Methods Enzymol. 235:329-344.

Penrose, D.M. and B.R. Glick. 2003. Methods for isolating and characterizing ACC deaminase-containing plant growthpromoting rhizobacteria. Physiol. Plant. 118:10-15.

Rahman, M.M., C.M. Escobedo-Bonilla, M. Corteel, J.J. Dantas-Lima, M. Wille, V. Alday Sanz, M.B. Pensaert, P. Sorgeloos, and H.J. Nauwynck. 2006. Effect of high water temperature $\left(33^{\circ} \mathrm{C}\right)$ on the clinical and virological outcome of experimental infections with white spot syndrome virus (WSSV) in specific pathogen-free (SPF) Litopenaeus vannamei. Aquaculture. 261:842-849.

Relwani, L., P. Krishna, and M.S. Reddy. 2008. Effect of carbon 
and nitrogen sources on phosphate solubilisation by a wild type strain and UV-induced mutants of Aspergillus tubigensis. Curr. Microbiol. 57:401-406.

Reyes, I., L. Bernier, and H. Antoun. 2002. Rock phosphate solubilization and colonization of maize rhizosphere by wild and genetically modified strains of Penicillium rugulosum. Microb. Ecol. 44:39-48.

Saitou, N. and M. Nei. 1987. The neighbor-joining method: A new method for reconstructing phylogenetic trees. Mol. Biol. Evol. 4:406-425.

Saleena, L.M., S. Rangarajan, and S. Nair. 2002. Diversity of Azospirillum strains isolated from rice plants grown in saline and nonsaline sites of coastal agricultural ecosystem. Microb. Ecol. 44:271-277.

SAS (1999). SAS/STAT User's Guide Version 8. SAS, Cary, NC.

Scervino, J.M., M.P. Mesa, I.D. Mônica, M. Recchi, N.S. Moreno, and A. Godeas. 2010. Soil fungal isolates produce different organic acid patterns involved in phosphate salts solubilization. Biol. Fertil. Soils. 46:755-763.

Schwyn, R. and J.B. Neilands. 1987. Universal chemical assay for detection and determination of siderophores. Anal. Biochem. 160:47-56.

Silini-Cherif, H., A. Silini, M. Ghoul, and S. Yadav. 2012. Isolation and characterization of plant growth promoting traits of a rhizobacteria: Pantoea agglomerans Ima2. Pakistan J. Biol. Sci. 15:267-276

Son, H.J., G.T. Park, M.S. Cha, and M.S. Heo. 2006. Solubilization of insoluble inorganic phosphates by a novel salt and $\mathrm{pH}$ tolerant Pantoea agglomerans R-42 isolated from soybean rhizosphere. Bioresour. Technol. 97:204-210.

Souchie, E.L., O.J. Saggin-Junior, E.M.R. Silva, E.F.C. Campello, R. Azcón and J.M. Barea. 2006. Communities of P-solubilizing bacteria, fungi and arbuscular mycorrhizal fungi in grass pasture and secondary forest of Paraty, RJ-Brazil. An Acad. Bras. Cienc. 78:1-11.

Thompson, J.D., T.J. Gibson, F. Plewniak, F. Jeanmougin, and D.G. Higgins. 1997. The clustal $\mathrm{x}$ windows interface: flexible strategies for multiple sequence alignment aided by quality analysis tools. Nucleic Acids Res. 25:4876-4882.

Viruel, E., M.E. Lucca, and F. Sineriz. 2011. Plant growth promotion traits of phosphobacteria isolated from puna, Argentina. Arch. Microbiol. 193:489-496

Viveros, O.M., M.A. Jorquera, D.E. Crowley, G. Gajardo, and M.L. Mora. 2010. Mechanism and practical considerations involved in plant growth promotion by rhizobacteria. J. Soil Sci. plant Nutr. 10:293-319.

Zaidi, A., M.S Khan, and M.D. Amil. 2003. Interactive effect of rhizotrophic microorganisms on yield and nutrient uptake of chickpea (Cicer arietinum L.). Eur. J. Agron. 19:15-21. 